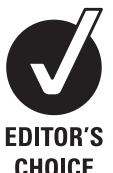

CHOICE
School of Public Health University of Sydney, Sydney, New South Wales, Australia

\section{Correspondence to} Becky Freeman, A27-School of Public Health, Room 129A, University of Sydney, Sydney, NSW 2006, Australia;

bfreeman@health.usyd.edu.au

Received 21 July 2009 Accepted 14 December 2009

\title{
British American Tobacco on Facebook: undermining article 13 of the global World Health Organization Framework Convention on Tobacco Control
}

\author{
Becky Freeman, Simon Chapman
}

\begin{abstract}
Background The World Health Organization Framework Convention on Tobacco Control (WHO FCTC) bans all forms of tobacco advertising, promotion and sponsorship. The comprehensiveness of this ban has yet to be tested by online social networking media such as Facebook. In this paper, the activities of employees of the transnational tobacco company, British American Tobacco, (BAT) on Facebook and the type of content associated with two globally popular BAT brands (Dunhill and Lucky Strike) are mapped.
\end{abstract}

Methods BAT employees on Facebook were identified and then the term 'British American Tobacco' was searched for in the Facebook search engine and results recorded, including titles, descriptions, names and the number of Facebook participants involved for each search result. To further detail any potential promotional activities, a search for two of BAT's global brands, 'Dunhill' and 'Lucky Strike', was conducted.

Results Each of the 3 search terms generated more than 500 items across a variety of Facebook subsections. Discussion Some BAT employees are energetically promoting BAT and BAT brands on Facebook through joining and administrating groups, joining pages as fans and posting photographs of BAT events, products and promotional items. BAT employees undertaking these actions are from countries that have ratified the WHO FCTC, which requires signatories to ban all forms of tobacco advertising, including online and crossborder exposure from countries that are not enforcing advertising restrictions. The results of the present research could be used to test the comprehensiveness of the advertising ban by requesting that governments mandate the removal of this promotional material from Facebook.

\section{INTRODUCTION}

The World Health Organization Framework Convention on Tobacco Control (WHO FCTC), now ratified by 165 nations, ${ }^{1}$ seeks in part to end the cycle of governments needing to amend legislation to address novel tobacco promotional methods not anticipated by existing provisions. The guidelines for implementation of the FCTC tobacco advertising, promotion and sponsorships (TAPS) Article 13 are clear that a ban must be applicable to all forms of TAPS in order to be effective. ${ }^{2}$ However, the comprehensiveness of this article has yet to be tested by the explosive advent of online social media and the challenges it brings for national governments in addressing a global communication medium.

Online social networking is often disparaged as little more than a vehicle for youth to spend hours updating friends on the trivia of their daily life This limited stereotype ignores how social networking websites such as Facebook, Twitter, YouTube, MySpace, Bebo and LinkedIn are also used to unite people with common interests and to disseminate content in ways and at speeds that were previously unimaginable. Online social networking 'involves the explicit modelling of connections between people, forming a complex network of relations, which in turn enables and facilitates collaboration and collaborative filtering processes'. ${ }^{3}$ Unlike traditional forms of advertising that seek to target customers with advertisements, companies and marketers that successfully join in this 'complex network of relations' seek to 'befriend' their customers by incorporating them into cyberspace social networks. Social network marketing is especially appealing to companies wanting to influence consumers to express their personality through brand association. Tobacco brands with a visual presence on social networking personal pages can be likened to the promotional power of smokers displaying their preferred brand packages on a restaurant table or bar. ${ }^{4}$

One of the most successful online social networking sites is Facebook (http://www.facebook. com). ${ }^{5}$ The exponential growth of Facebook since its launch in February 2004 has seen it attract more than 350 million users worldwide by December 2009. ${ }^{6}$ Collectively, users daily spend more than 3.5 billion minutes on the Facebook site and have caught the attention of marketers, academics, ${ }^{8} 9$ human resources managers, ${ }^{10}$ and even American presidential candidates. Barack Obama's election to the White House has been partly credited to his sophisticated and interactive online campaign, ${ }^{11}$ which included a Facebook profile that attracted 6.4 million supporters. ${ }^{12}$ As of June 2009, President Obama had the most popular Facebook page, ahead of international brands such as Coca Cola in 9th place and Starbucks Coffee Company in 10th. ${ }^{13}$ Companies and brands that can successfully engage with the vast communities of Facebook users have the potential to reap significant financial rewards. Given that the tobacco industry has a history of exploiting novel and emerging advertising methods, ${ }^{14} 15$ it would be surprising if social networking sites were not being used as vehicles for tobacco product promotion.

\section{WHAT IS FACEBOOK?}

Facebook was originally devised as an online tool to connect fellow students at Harvard University 
It quickly expanded to include other universities and the wider public. Today, it is an international forum which attracts companies and brands wanting to 'reach[ing] people where they're already sharing, linking, publishing and tagging, and becoming another node on their social networks by interacting with them and adding value to their experiences online'. ${ }^{16}$ According to its corporate website, Facebook is 'a social utility that helps people communicate more efficiently with their friends, family and coworkers'. ${ }^{17}$ Since its inception, Facebook developers recognised its commercial potential and there is a selection of marketing tools and platforms available to advertisers that meld with the social aspects of the site. Each Facebook user has a profile page where they post information about themselves, including a photograph, demographics, email address, likes/dislikes etc. The most basic level of interaction is for users to link their profile page to those of other users by initiating and accepting 'friend' invitations.

\section{Who uses Facebook?}

Facebook users reside on every continent including Antarctica and the site is used by speakers of more than 50 different languages and in 180 countries and territories. ${ }^{6}$ Users are from all age groups, serving to further its appeal to advertisers as Facebook cannot be a 'standardised platform if only cool kids use it'. ${ }^{18}$ In December 2009, of the 350 million users, 65 million currently access Facebook through their mobile devices. ${ }^{19}$ This is a significant statistic as there are now more mobile phone users in low-income and middle-income countries (LMICs) than highincome countries. $^{20}$ Mobile phone use, coupled with the increased uptake of wireless networks in LMICs, greatly increases the reach of online social networking. ${ }^{21}$ Clearly, Facebook has mass population appeal and is not purely limited to the wealthy or the technologically advanced.

As tobacco markets shrink in high-income countries, globalisation has enabled tobacco companies to widen their focus to LMICs. $^{22}$ Given the globalising effects of communications technology, ${ }^{23}$ reaching these potential consumers through online media may be a highly efficient strategy. The challenge of maintaining market share in high-income countries that have severely limited tobacco advertising may also be aided by online promotions, where the tobacco industry has already proven itself adept. ${ }^{2425}$ A review of the effects of TAPS identified the need for further research on the extent to which tobacco is being promoted on social networking websites. ${ }^{26}$ In this paper, we explore and map the activities of employees of the transnational tobacco company, British American Tobacco, (BAT) on Facebook and the type of content associated with two globally popular BAT brands in order to increase understanding of how tobacco companies may be utilising online promotional opportunities. We selected this transnational tobacco company as it is the "the most international of tobacco companies'. ${ }^{27}$

\section{How Facebook works: some basics}

Given the limited body of published research on the public health implications of social networking sites, there are few examples on which to model research methods. Other social networking researchers have surveyed users about their usage patterns. ${ }^{28-30}$ However, given the 'under siege' nature of tobacco marketing in many nations and the history of clandestine promotional efforts implemented after tobacco advertising bans, ${ }^{31} 32$ any attempt to interview tobacco industry representatives about how they might be exploiting online social networks would be naive. Instead, we sought to locate, describe and interpret content on Facebook relevant to BAT and its brands.

As with other user-generated content driven websites, ${ }^{33}$ key word searches can be conducted on Facebook. As new content is continually uploaded and deleted from the site, search results invariably change from search to search when using an identical term. Facebook searches can be undertaken across different content categories, including: people, groups, networks, events, pages and applications. People (in Facebook terms) are those who have individual Facebook profile pages. Depending on the level of privacy settings activated by each individual, only limited personal information can be viewed by others unless the individual has accepted a 'friend' request from the person doing the search. Most individuals on Facebook have a public profile that only displays limited information including their name, any networks to which they belong, a personal photograph and the list of their Facebook friends. (Figure 1 is an example of two publicly accessible profiles for individuals who work for BAT.)

Once you are 'friends' with someone it is possible to view his/ her profile page in full and also to comment on any content posted on their page. Facebook functionality is such that sharing, tagging, sending, receiving, notifying and inviting is easily accomplished though updates to all 'friends'. In practice, this means when a user participates in a Facebook activity all the user's friends are automatically alerted to that activity because it appears on the user's personal profile page and the constantly updated news feed sent to all their friends. For companies wanting advertising content to be spread virally this is an especially attractive feature. If each Facebook user has on average 120 friends, ${ }^{34}$ information can be spread rapidly through this web of contacts.

Networks link individuals who may not have a personal connection but who have a common link such as a shared workplace, city of residence, secondary school or university. Networks must be created by Facebook staff and are based on suggestions from users. Some networks require users to confirm their connection, such as providing a valid email address, before being permitted to join. Groups are where Facebook members with a common interest or association can join together and share content. Groups can be open, allowing anyone on Facebook to join, or closed, meaning that members must meet
Figure 1 Screen capture image of how a list of individual people profiles appear when conducting a subject key word search, in this case the search term 'British American Tobacco Australia' was entered on 9 July 2009.

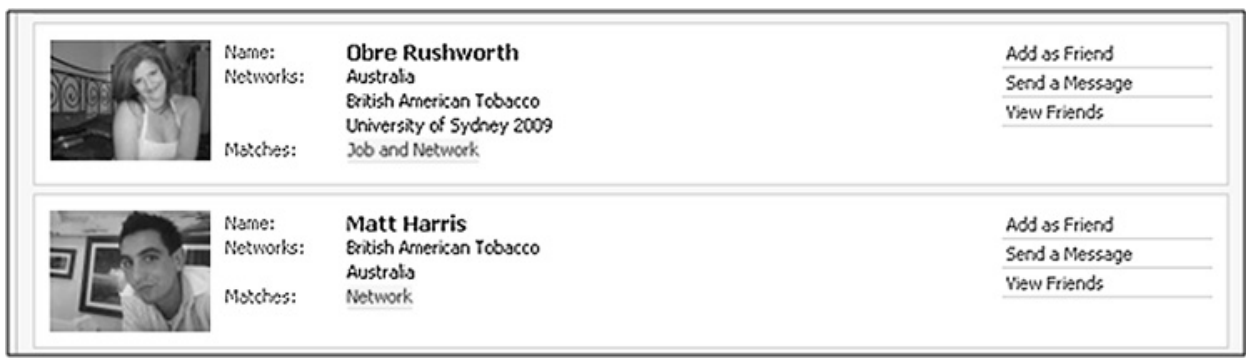


Figure 2 Screen capture images of an open group for Lucky Strike cigarettes on 9 July 2009.

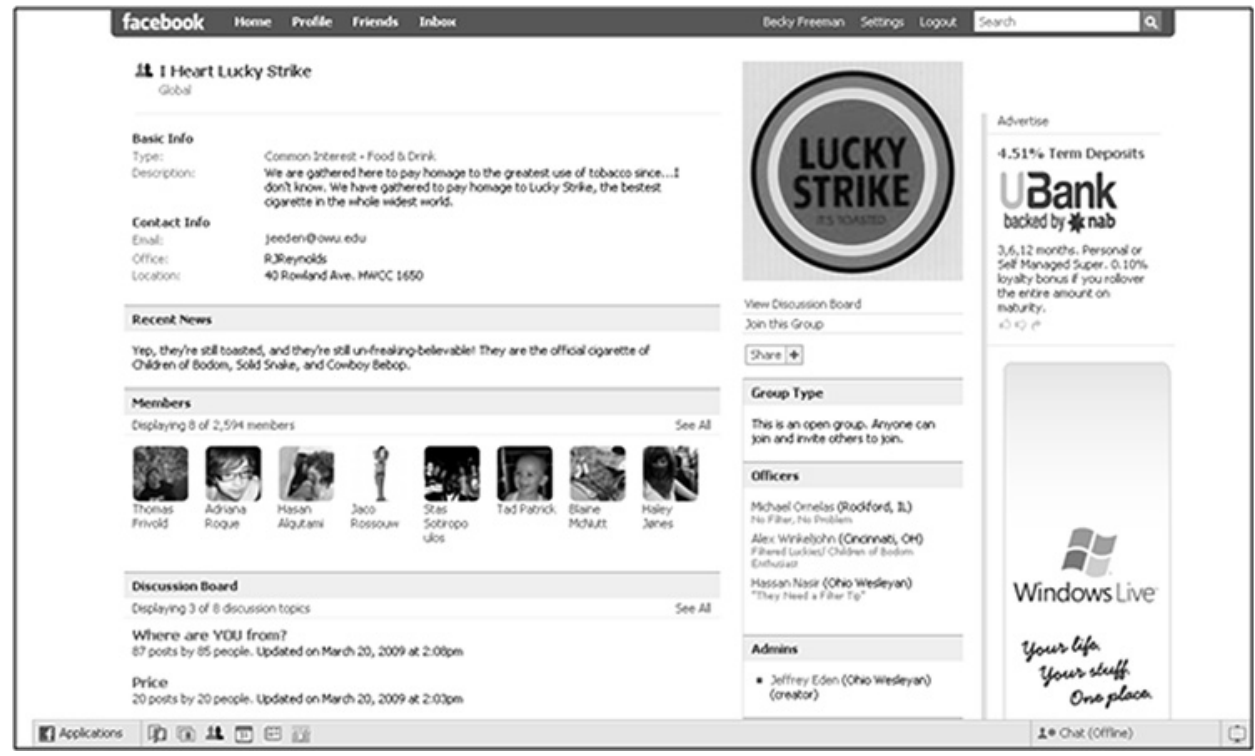

eligibility criteria to be admitted by the group administrators. (Figure 2 is an example of a Lucky Strike group.) It is possible to view the membership list of open and closed Groups and the content of open groups can also be viewed without being a member of the group. Events can include parties, demonstrations, festivals and, as with groups, can be open to all Facebook users or by invitation only. When conducting a search for events, only current or future events will appear in the result list, but not events that have already taken place. Any Facebook user can instantly create a group or an event.

Pages are a 'public profile that enables you to share your business and products with Facebook users'. ${ }^{35}$ Pages were created by Facebook specifically for the promotion of products, services and brands (including celebrities). Significantly, pages look and have identical features to user profiles and are specifically designed for connecting and engaging with customers and amplifying promotion to the customer's friends. ${ }^{36}$ When a Facebook user joins a page they are described as being 'a fan' and their name appears on the page. These pages then appear in the 'all connections' listing on a personal profile page, grouped together with the person's friends. Essentially, Facebook pages allow customers and companies to be 'friends'. There are clear rules about who can create a Facebook page. A creator must "certify that you are an official representative of this brand, organisation, or person and that you are permitted to create a Facebook page for that subject'. Fake pages and unofficial fan pages are a violation of terms of use and violators may have their Facebook account disabled.

Significantly, this technically means that only BAT employees or agencies or persons authorised by BAT could legitimately create pages for BAT brands on Facebook. Figure 3 is a screen capture of the first step in creating a page that includes the certification. The creator/leader of the page is then the name of the page itself. For example, a page called 'Lucky Strike Tobacco' will show all activity, including any messages or posting of images, undertaken by the page creator as being undertaken by 'Lucky Strike Tobacco'. Fans who join a page do not know the name of the actual person who created the page and under Facebook's own rules can only assume that an official representative of the brand created the page. Facebook is primarily a self-regulated site where users report suspected violations or objectionable content to Facebook administrators for investigation.
Applications are programs that Facebook users can use to enhance their profile page or facilitate interactions with other users. These programs can be developed by anyone by using the Facebook platform interface for software developers. Common applications allow users to upload photos, videos, music and web links. However, applications also allow users to play games, support charities and share more detailed information about their likes and dislikes. For example, a hugely popular application, (more than 31 million monthly active users as of 30 April 2009) LivingSocial, allows users to catalogue their 'top 5' across virtually any category, including cigarettes. (Figure 4 is an image of the first three entries for cigarette brands.) This information is then displayed on the users profile for friends to view, comment on, copy and forward to others.

\section{METHODS}

We first searched the Facebook network list to determine if it would be possible to identify BAT employees who were active on Facebook. On 15 May 2009, we entered the term 'British American Tobacco' in the 'Join a Network' feature under the 'My Account' settings on a personal profile page and found that BAT has a network that requires users to enter a BAT work email

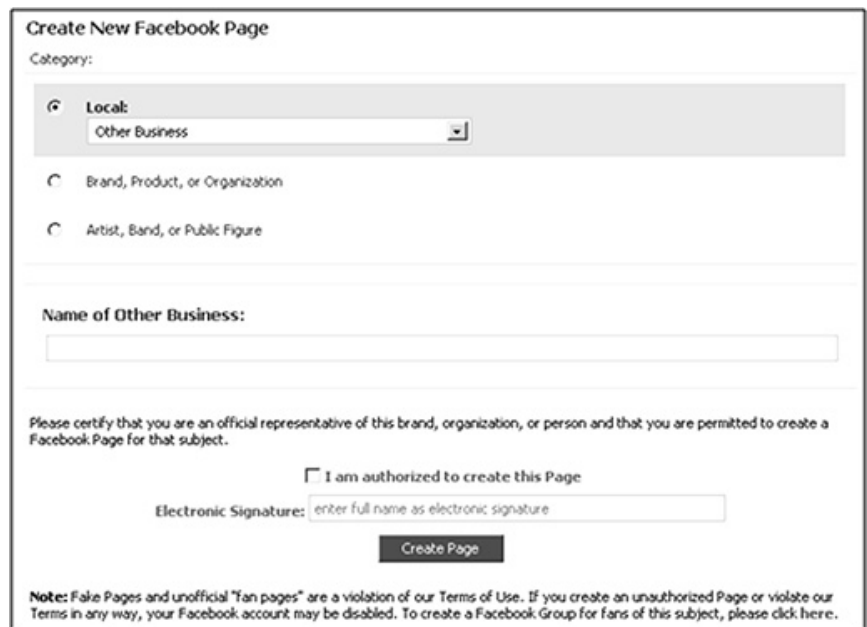

Figure 3 Screen capture of the first step in creating a Facebook page accessed 9 July 2009. 
Figure 4 LivingSocial application showing the first three results for the 'top 5 cigarette' category (accessed 15 June 2009).

\section{Most Popular Fives}
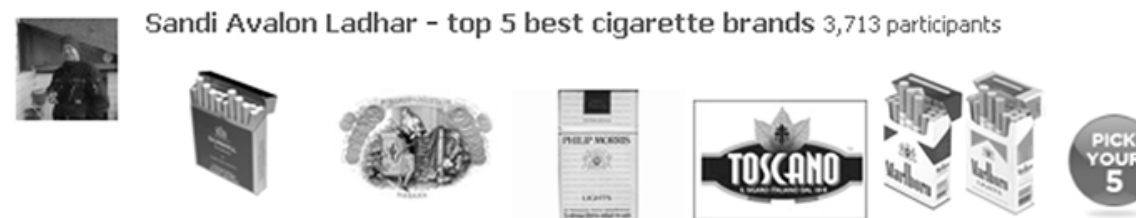

Sandi Avalon Ladhar chose dunhill, Romeo y Julieta, philip morris, Toscano, marlboro.
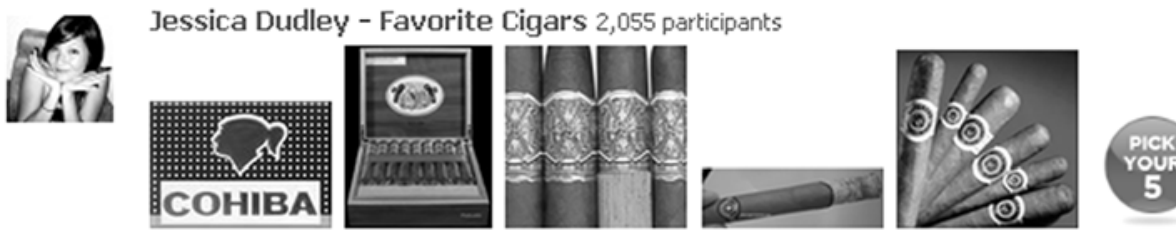

Jessica Dudley chose Cohiba, Romeo y Julieta Anniversario, Arturo Fuente Opus X, Montecristo Double Corona, Macanudo.

Report abuse

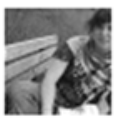

Michelle Nelson - my favorite cigarettes! 1,694 participants
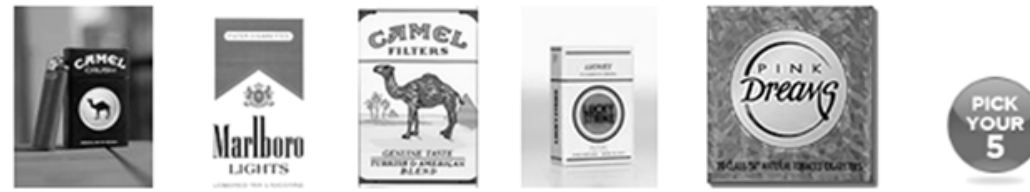

Michelle Nelson chose Camel Crush, Marlboro Lights, Camel Filters, Lucky Strike, Cherry Dreams.

Report abuse

to be eligible join. (See Figure 5 for a screen capture image of how to join the BAT network.) Any BAT employee who joins this network will then have the BAT network name listed beneath their name on any subsequent action or activity in which they participate on Facebook, making it possible to determine if BAT employees are engaged in product, company or brand promotion. Importantly, BAT employees not wishing to reveal their BAT employment to others could also start a private Facebook account using a real or pseudonym and engage in tobacco promotional activity. This would be impossible to detect.

\section{Search strategies}

Next, we searched all Facebook content with the same search term, 'British American Tobacco' and recorded results, including names, descriptions and numbers of Facebook participants involved for each item in an Excel spreadsheet. The results

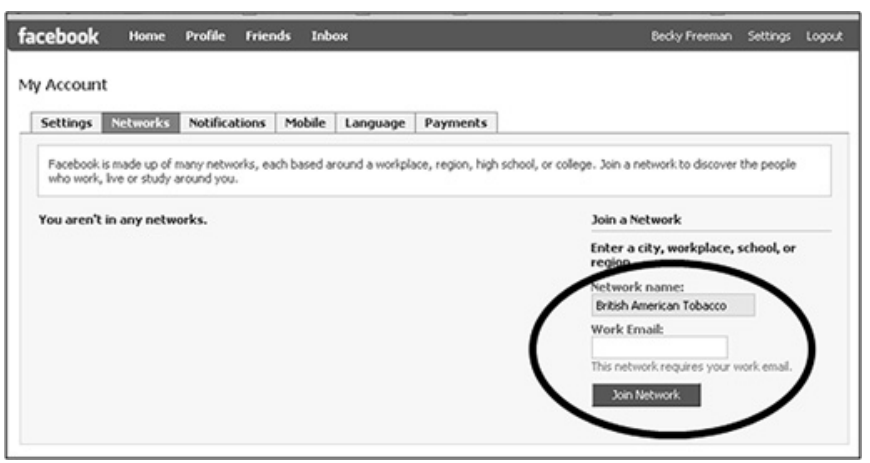

Figure 5 Screen capture image of the British American Tobacco network on 9 July 2009. obtained were from four Facebook categories of people, groups, events and applications. All 'groups' results were then assigned to one of seven categories corresponding to the purpose of the group: BAT employee group (companywide and regional), BAT cigarette brand group, advertising or promotion agency group, anti-BAT or anti-smoking, recruitment/career opportunity, protobacco use, or other (not a tobacco or tobacco control focus). These seven categories emerged after documenting the name, size, type and description of the group and were chosen on the basis of the observational data collected. These categories were determined after viewing the full results of our search and were chosen based on the content we documented. Additionally, we viewed the membership list for each group and noted if any individual members were identified as BAT employees in their personal profile.

After completing this initial search, we reasoned that tobacco users were more likely to search for and join Facebook groups/ pages/events featuring their favoured tobacco brand rather than a group named after the BAT company itself. To further detail any potential promotional activities we then searched, on 15 June 2009, for two of BAT's 'global drive brands', Dunhill and Lucky Strike. $^{37}$ The results from these two searches were from the five Facebook categories of people, groups, pages, events and applications. All groups, pages, events and applications were then recorded in an Excel spreadsheet including the name, type and size for each result. Results that contained the search terms

Table 1 Search results for 'British American Tobacco'

\begin{tabular}{llllll}
\hline & All & People & Groups & Events & Applications \\
\hline British American Tobacco & $500+$ & $500+$ & 96 & 0 & $1^{*}$
\end{tabular}

*The one application result in the search did not relate to British American Tobacco (BAT) 
Table 2 Summary of results for the 96 groups located in our search for 'British American Tobacco'

\begin{tabular}{|c|c|c|c|c|c|}
\hline Type of group & $\begin{array}{l}\text { Number of } \\
\text { groups }\end{array}$ & $\begin{array}{l}\text { Number with closed } \\
\text { membership }\end{array}$ & $\begin{array}{l}\text { Number with open } \\
\text { membership }\end{array}$ & $\begin{array}{l}\text { Range of } \\
\text { number } \\
\text { of members }\end{array}$ & $\begin{array}{l}\text { Number of the groups } \\
\text { with BAT network } \\
\text { members }\end{array}$ \\
\hline $\begin{array}{l}\text { BAT employee group } \\
\text { (companywide and } \\
\text { regional) }\end{array}$ & 32 & 10 & 22 & $1-1090$ & 21 \\
\hline $\begin{array}{l}\text { BAT cigarette brand } \\
\text { group }\end{array}$ & 26 & 2 & 24 & $1-685$ & 5 \\
\hline $\begin{array}{l}\text { Advertising or } \\
\text { promotion agency } \\
\text { group }\end{array}$ & 12 & 4 & 8 & $7-1724$ & 0 \\
\hline $\begin{array}{l}\text { Anti-BAT or anti- } \\
\text { smoking }\end{array}$ & 11 & 0 & 12 & $13-3025$ & 0 \\
\hline $\begin{array}{l}\text { Recruitment/career } \\
\text { opportunity }\end{array}$ & 2 & 0 & 2 & $242-573$ & 1 \\
\hline Pro-tobacco use & 2 & 0 & 2 & $31-105$ & 0 \\
\hline $\begin{array}{l}\text { Other (not a tobacco o } \\
\text { tobacco control focus) }\end{array}$ & or $3^{*}$ & 0 & 3 & $23-55$ & 0 \\
\hline
\end{tabular}

*The remaining eight groups had the search words British, American and Tobacco in the description but did not refer to British American Tobacco (BAT) directly.

but which did not relate to the tobacco brands searched were deleted from the search. We viewed the membership list of all groups and pages that contained more than 200 members, and noted any BAT employee members. We chose to look closely only at the larger groups and pages because one of the first things Facebook users assess when deciding to join these forums is the number of members, the larger the number of member the more authoritative, important and attractive the source is seen to be. ${ }^{38}$

As we reviewed BAT employee membership and participation on various Facebook pages, we noted examples of BAT employee activity and BAT brand promotions that contributed to tobacco product marketing on Facebook. We provide illustrative examples below.

\section{RESULTS}

Entering the search term 'British American Tobacco' in the Facebook search engine yielded more than 500 results across the 4 subcategories (table 1 ).

Examining the first 50 public profiles of the more than 500 individuals found under the 'people' category revealed (unsurprisingly) that employees have joined the existing BAT network (see figure 1 for how this is displayed on the public profile of each employee). This means BAT employees can be readily identified on Facebook. However, unless BAT employees are actually required by their employer to join this network this does not mean that all BAT employees who have Facebook accounts are part of this network. Therefore, it is possible that some other BAT employees will be active on Facebook but we would be unable to confirm that they were BAT employees.

A total of 96 groups were found that contained the search term, British American Tobacco (table 2). The most common type of group, with 32 results, was designed for BAT employees, either companywide or in different regional offices, to connect with each other; 21 of these groups had members who also belonged to the BAT network. The largest BAT work-related group is a closed group of 1090 members called British American Tobacco Worldwide. For example, the BAT South Africa group, an open group with 121 members, was created by Lorynne McGurk Heynes (South Africa) who describes herself as 'a Consumer Relations Amplifier for Peter Stuyvesant (drive brand) at British American Tobacco South Africa'. Another group of this type, The British American Tobacco \& Tekel-Türkiye group, an open group with
128 members, hosts a collection of 65 photos that showcase a variety of tobacco powerwall and retail displays for BAT brands. Two additional groups that were similar to the BAT employee groups were for career development and recruitment.

The next most common type of group was for BAT cigarette brands. In all, 26 BAT cigarette brand groups were found as part of the search and of these, 5 had members who were part of the BAT network. The largest of these, for Kent cigarettes, is an open group with 685 members including 131 members (as of 15 May 2009) who are part of the BAT network. A photo of Kent promotional items including novelty split packs and lighters was posted on the site by BAT employee Kristof Desmedt, of Belgium (figure 6). Facebook groups must indicate what 'type' of group they are when developing a group profile. Six of the brand groups are designated as 'health and wellbeing' type of group. For example, a Spanish group in support of Lucky Strikes, 'solo fumadores de LUCKY STRIKE', urges people not to smoke counterfeit Lucky Strike cigarettes as these are said to be 'more toxic'.

Our search located 12 groups that belonged to advertising or promotion agencies and which had British American Tobacco listed as a current or former client on their Facebook pages. One such agency, Lemonade Advertising, describes itself on the group page as specialising in 'guerrilla advertising... and unconventional brand communication tactics and campaigns' further explaining that 'traditional channels of TV, print and outdoors are no longer the most effective methods for a brand to reach its target audience'. Guerrilla marketing means using non-traditional media in unique and creative ways, and generally at very low cost, with a goal of producing memorable campaigns. ${ }^{39}$

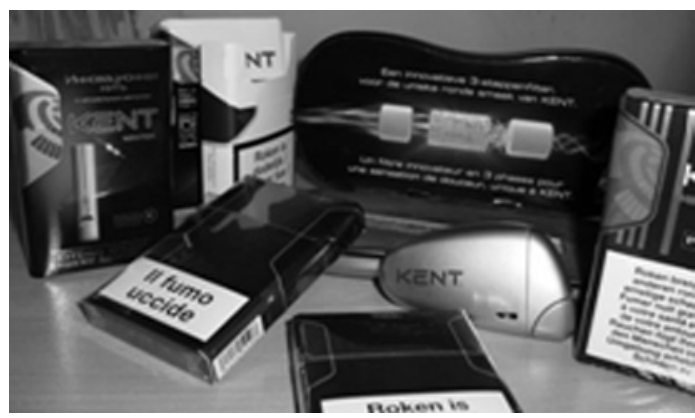

Figure 6 Photo of Kent promotional items posted by a BAT employee on the 'Kent Cigarettes' group. 
Table 3 Search results for 'Dunhill' and 'Lucky Strike'

\begin{tabular}{llllcc}
\hline & All & People & Pages & Groups & Events \\
\hline Dunhill & $500+$ & $500+$ & 17 & 73 & 4 \\
Lucky Strike & $500+$ & $500+$ & 72 & 384 & 75 \\
\hline
\end{tabular}

A total of 11 anti-BAT or anti-smoking groups that mention BAT were also in the group results list. An example of this type of group is 'Stop British American Tobacco', a group that highlights BAT's activities in Africa. ${ }^{40}$ Only two explicitly 'protobacco use' groups were located by our search; these groups did not promote a particular BAT brand or the company itself and as such are listed separately from the BAT employee group and cigarette brand groups, and neither of these groups had people from the BAT network as members.

\section{Results for the search terms Dunhill and Lucky Strike}

Entering the search terms 'Dunhill' and then separately 'Lucky Strike' in the Facebook search engine on 15 June 2009 yielded more than 500 results across 4 subcategories (table 3 ).

\section{Dunhill results}

Of the resulting 17 pages, 6 were for fans of the Dunhill brand. The total number of fans on these 6 pages was 1903 (the range of numbers of fans per page was 2-1333); 2 pages had more than 200 fans and of these the largest page had BAT employees as fans. A total of 43 of the resulting groups were promoting the Dunhill tobacco brand. The total number of members for these groups was 3632 (the range of number of members per group was 1-640) (table 4). Two of the four events related to the Dunhill tobacco brand and were for parties hosted by Dunhill at a nightclub in Kingston, Jamaica, which promised 'free Dunhill cigarettes all night long' ${ }^{41}$ The remaining pages, groups and events contained the search term Dunhill but did not relate directly to the tobacco brand; however 11 groups, 5 pages and the remaining 2 events promoted the Dunhill fragrance and luxury goods brand, which can be considered a form of brandstretching promotion. ${ }^{42}$

\section{Lucky Strike results}

Lucky Strike is a popular brand on Facebook, with more than 10 times as many fans as Dunhill. Of the resulting 72 pages, 44 promoted the Lucky Strike brand. A total of 28309 fans were part of these pages (the range of number of fans per page was 3-10 062). In all, 10 pages had more than 200 fans, with 4 of these pages having BAT employees as fans. Of the resulting 384

Table 4 Summary of the groups and pages that promoted the brands Dunhill or Lucky Strike

\begin{tabular}{|c|c|c|c|c|c|}
\hline $\begin{array}{l}\text { Pages/ } \\
\text { groups }\end{array}$ & Number & $\begin{array}{l}\text { Total fans/ } \\
\text { members }\end{array}$ & $\begin{array}{l}\text { Range of } \\
\text { fans/ } \\
\text { members } \\
\text { per page }\end{array}$ & $\begin{array}{l}\text { Pages with } \\
>200 \text { fans/ } \\
\text { members }\end{array}$ & $\begin{array}{l}\text { Pages with } \\
\text { BAT } \\
\text { network } \\
\text { members } \\
\text { as fans/ } \\
\text { members }\end{array}$ \\
\hline \multicolumn{6}{|l|}{$\begin{array}{l}\text { Pages (with } \\
\text { fans) }\end{array}$} \\
\hline Dunhill & 6 & 1903 & $2-1333$ & 2 & 1 \\
\hline Lucky Strike & 44 & 28309 & $3-10062$ & 10 & 4 \\
\hline \multicolumn{6}{|l|}{$\begin{array}{l}\text { Groups } \\
\text { (with } \\
\text { members) }\end{array}$} \\
\hline Dunhill & 43 & 3632 & $1-640$ & 4 & 2 \\
\hline Lucky strike & 341 & 18162 & $1-2612$ & 14 & 5 \\
\hline
\end{tabular}

groups, 341 were promoting the Lucky Strike brand. These Lucky Strike groups had a total of 18162 members (the range of number of fans per page was 1-2612 members). Of these groups, 14 had more than 200 members with 5 of these groups including BAT employees (table 4). One event, hosted by Lucky Strike, was for a cocktail party in Borgoricco, Italy and also promised free cigarettes. ${ }^{43}$ The remaining pages, groups and events contained the Lucky Strike search term but did not relate to the tobacco brand. (Lucky Strike also refers to the name of American bowling alleys, which dominated the events results.)

In our search for the promotion of the 2 BAT brands we found 12 groups and pages with active participation by BAT employees. On one such page, called Lucky Strike Cigarettes, (figure 7) 1 of 38 BAT employee members, Kristof Desmedt of Belgium (figure 8) had posted a photo of promotional Lucky Strike items on the fan page (figure 9). This fan page had a total 3412 fans as of 15 June 2009. A posting on the page by 'Lucky Strike Cigarettes' encouraged fans to post their best Lucky Strike photos: 'C'mon all you!!! [fill up our] site with ALL THE PICS THAN ALL YOU GUYS WANT UPLOAD! AFTER WE GONNA MAKE A 'VOTATION' FOR LEAVE THE BEST PIC ON OUR PROFILE!!! :D'

A group called 'LUCKY STRIKE FUN', with 251 members, described as being 'a just for fun fan club' is administered by a BAT employee from Greece, Ioanna Sakketa (her public profile can be viewed here: http://www.facebook.com/profile.php? $\mathrm{id}=523328$ 977\&ref=sgm). Group administrators can 'control the membership and content of a group. Admins can send messages to the group, appoint other admins and edit group info and settings. They can also remove current members and other admins'. ${ }^{44}$ Groups are directly connected to those who administer them, meaning that activities reflect on the administrators personally. When something is posted by a group administrator, it appears to be coming from the administrator and is attached to their personal profile. ${ }^{45}$ This group has a gallery of vintage Lucky Strike adverts, photos from a car racing event and Lucky Strike brand ambassadors (Figure 10 for an example).

\section{DISCUSSION}

Some BAT employees are promoting BAT and BAT brands on Facebook by joining and administrating groups, joining pages as fans and posting photographs of BAT events, products and promotional items. BAT employees undertaking these actions are from countries that have ratified the WHO FCTC which requires signatories to ban all forms of TAPS, including online and any crossborder exposure from countries which are not enforcing advertising restrictions. ${ }^{2}$ Tobacco control organisations are encouraged to highlight these activities to their governments as a possible breach of the WHO FCTC. The results of our research could be used to test the comprehensiveness of the TAPS ban by requesting that governments mandate the removal of this promotional material from Facebook. As Facebook is largely selfregulating, this promotional content could also be reported to the site administrators as a violation of existing tobacco advertising laws. As a caveat however, we believe it is essential to distinguish between content that is commercial and personal in origin.

We urge the development of FCTC guidelines specifically for online TAPS monitoring and enforcement. FCTC signatory countries should allocate resources towards investigating, monitoring and applying existing advertising bans to new media, especially for content that is clearly commercial in origin. Just as traditional forms of media such as newspapers, magazines and television stations would be prosecuted for publishing or 
Figure 7 Screen capture image of the 'Lucky Strike Cigarettes' page.

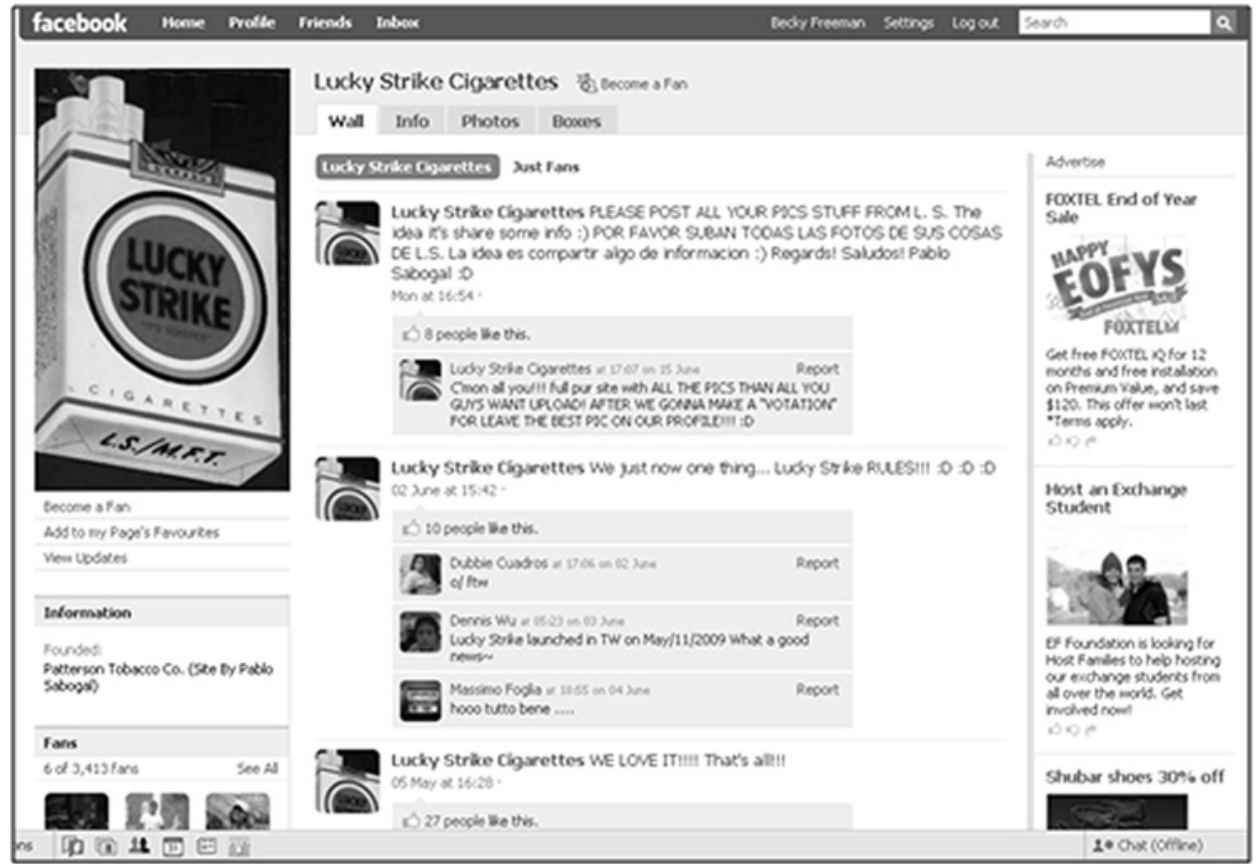

broadcastings TAPS (in countries that have comprehensive advertising bans), new media must be held to these same standards. In response to the preliminary findings of our research, the Australian Federal Health Minister announced in October 2009, that she would be launching an investigation into the online promotion of tobacco products. ${ }^{46}$ In order to build a comprehensive understating of online tobacco promotions, other governments should conduct and share the findings of their own enquiries.

It is not possible to determine who created the Facebook pages that promoted the Dunhill and Lucky Strike brands. However, according to Facebook's own rules of conduct these pages should have been created by persons authorised by BAT. It is also possible that these pages were created by private fans of BAT brands. However, given that BAT employees have joined these pages as BAT network members, the company cannot claim to be unaware of these promotional activities. Further, the goal of online social networking is to intentionally create communities where fans of a brand can promote the products they like through 'word of mouse' marketing and engage with the companies making these products. ${ }^{47}$ Given that pages/groups with bigger numbers of members generate more interest, the

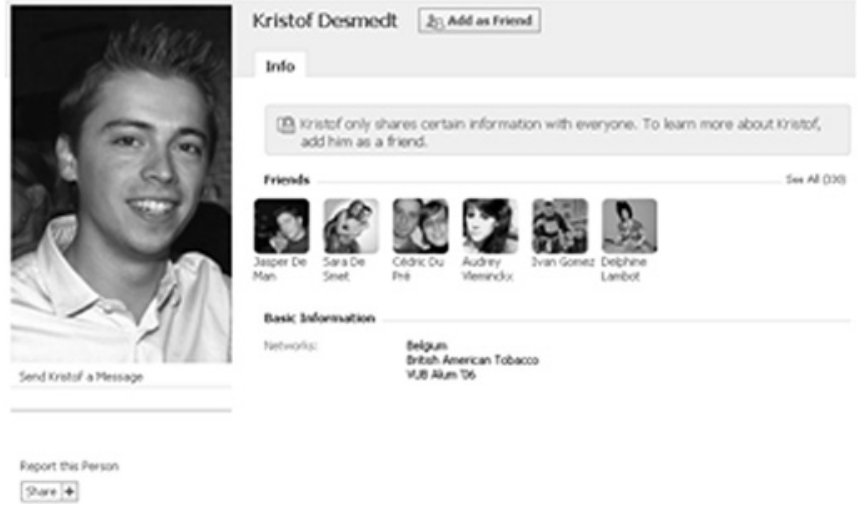

Figure 8 Public profile image of Belgium BAT employee Kristof Desmedt. high number of BAT employees on the Lucky Strike fan page and the Kent cigarettes group could have been a strategy to help drive traffic to the page/group. Even if BAT did not create these pages itself, it has not removed this content from Facebook.

While the majority of content on Facebook does not have a commercial purpose, commercial aspects such as tobacco brand promotion, are treated no differently than if users were to join a group for dog lovers or respond to an invitation to a $21 \mathrm{st}$ birthday party. This seems like an ideal platform for the tobacco industry with its negative public reputation, ${ }^{4849}$ to assist in the reinvention of itself as a modern, friendly and in every way normal industry. New media offer the tobacco industry a powerful and efficient channel for rapidly countering the denormalising strategies and policies of tobacco control.

Our research focused on one tobacco company and two international tobacco brands on one social networking site. Our findings therefore are likely to offer only a glimpse of the amount and number of online social networking forums that are

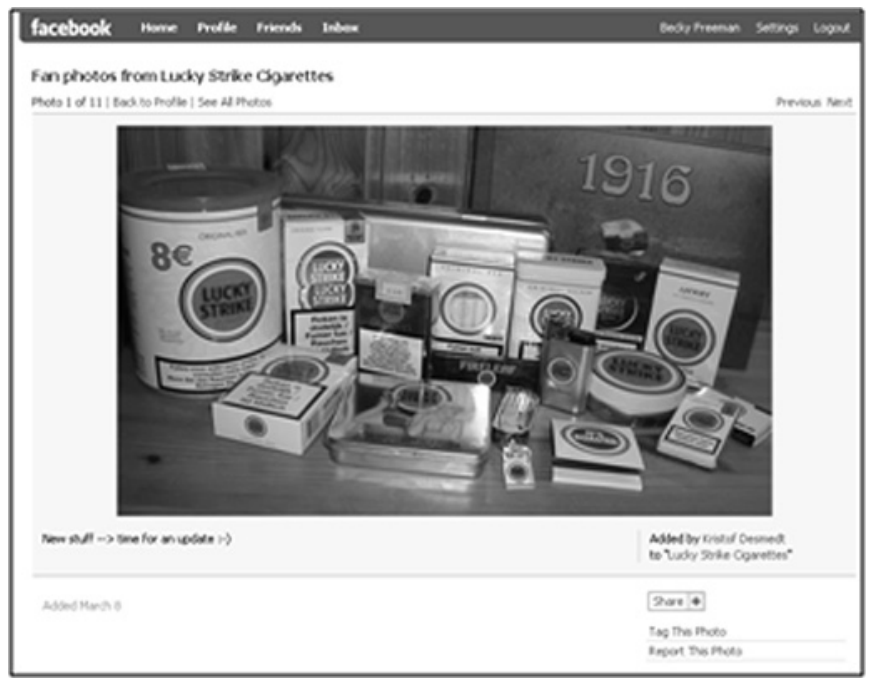

Figure 9 Image of promotional items posted on the 'Lucky Strike Cigarettes' page by BAT employee Kristof Desmedt. 


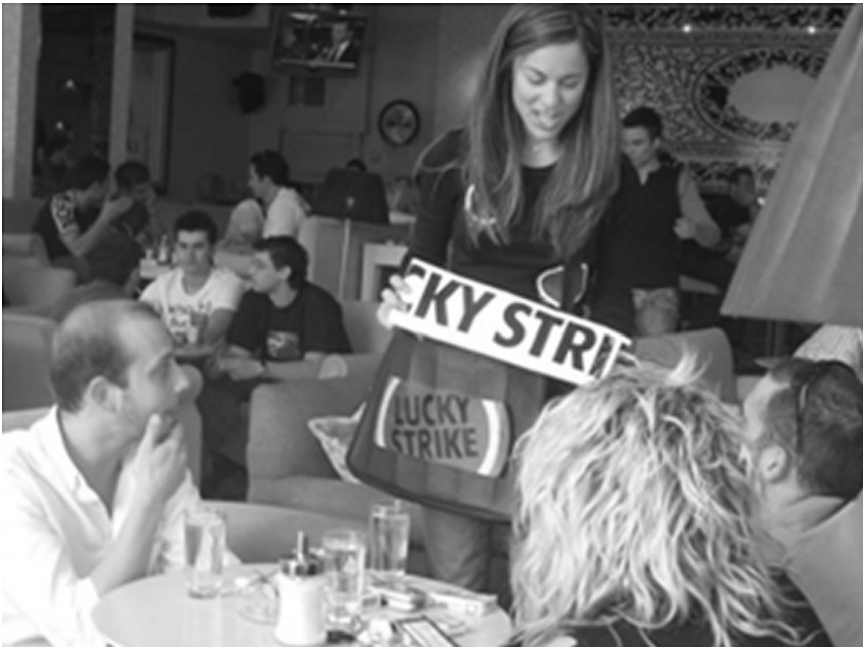

Figure 10 Photo of Lucky Strike brand ambassador as posted to the 'LUCKY STRIKE FUN' group.

promoting tobacco use, tobacco brands and tobacco companies. Additionally, it is also likely that tobacco companies hire advertising and public relations companies to conduct online marketing, making it far more difficult to track the origins of promotions. The international tobacco control community and governments should focus far greater attention on monitoring and documenting ways in which tobacco companies are utilising online social networking sites to promote smoking and brands. While the WHO FCTC embraces internet-based TAPS as important, the tobacco control workforce has largely failed to move its focus away from pre-web media in monitoring and analysing TAPS. Web-based surveillance poses mercurial challenges because it constantly changes with user activity. Such challenges are in nature of the medium and should not daunt stakeholders from engaging with this crucial and rapidly expanding TAPS playing field.

\section{What this paper adds}

- The World Health Organization Framework Convention on Tobacco Control (WHO FCTC) bans all forms of tobacco advertising, promotion and sponsorship. However, despite near universal adoption of advertising bans, the tobacco industry has a history of exploiting novel and emerging advertising methods.

- This is the first published paper to map the activities of employees of the transnational tobacco company, British American Tobacco, (BAT) on Facebook and the promotional content associated with two BAT brands (Dunhill and Lucky Strike). Some BAT employees are energetically promoting BAT and BAT brands on Facebook through joining and administrating groups, joining pages as fans and posting photographs of BAT events, products and promotional items. The results of our research should be used to test the comprehensiveness of existing tobacco advertising bans.

Acknowledgements This paper was supported by grant 570869 , funded by The National Health and Medical Research Council, Australia on the use of Web 2.0 internet sites to undermine tobacco advertising bans and to mobilise tobacco control advocates.
Funding This work was funded by grant 570869 , The National Health and Medical Research Council, Australia on the use of web 2.0 internet sites to undermine tobacco advertising bans and to mobilise tobacco control advocates.

\section{Competing interests None.}

Provenance and peer review Not commissioned; externally peer reviewed.

\section{REFERENCES}

1. World Health Organization. Full list of signatories and parties to the WHO Framework Convention on Tobacco Control, 2009. http://www.who.int/fctc/ signatories parties/en/index.html (accessed 25 Jun 2009).

2. Conference of the Parties (COP). Guidelines for implementation of Article 13 of the WHO Framework Convention on Tobacco Control (Tobacco advertising, promotion and sponsorship), 2008. http://www.who.int/fctc/guidelines/article 13.pdf (accessed 25 Jun 2009)

3. Eysenbach G. Medicine 2.0: social networking, collaboration, participation, apomediation, and openness. J Med Internet Res 2008:10:e22.

4. Wakefield M, Morley C, Horan JK, et al. The cigarette pack as image: new evidence from tobacco industry documents. Tob Control 2002;11(Suppl 1):i73-80.

5. Kazeniac A. Social networks: Facebook takes over top spot, Twitter climbs, 2009 http://blog.compete.com/2009/02/09/facebook-myspace-twitter-social-network/ (accessed 29 Jun 2009).

6. Facebook. General growth. Statistics, 2009. http://www.facebook.com/press/info. php?statistics\#/press/info.php?statistics (accessed 14 Dec 2009).

7. Needham A. Word of mouth, youth and their brands. Young Consumers 2008:9:60-2

8. Orton-Jones C. How Facebook can be used as a serious professional tool. Financial Management 2009:21.

9. Schleyer T, Spallek H, Butler BS, et al. Facebook for scientists: requirements and services for optimizing how scientific collaborations are established. J Med Internet Res 2008;10:e24.

10. Anon. Woo candidates with Web 2.0. Journal of Accountancy 2008;206:18.

11. Sullivan A. Barack Obama is master of the new Facebook politics. The Sunday Times, 2008. http://www.timesonline.co.uk/tol/comment/columnists/ andrew_sullivan/article3997523.ece (accessed 20 Apr 2009).

12. Barack Obama, 2009. http://www.facebook.com/barackobama (accessed $25 \mathrm{Apr}$ 2009).

13. All Facebook. Facebook page leaderboard, 2009. http://statistics.allfacebook.com/ pages/leaderboard/ (accessed 26 Jun 2009).

14. Freeman B, Chapman S. Chapter 11 Tobacco advertising and promotion. In: Scollo M Winstanley M, eds. Tobacco in Australia: Facts and Issues. 3rd edn. Melbourne: Cancer Council Victoria, 2008. http://www.tobaccoinaustralia.org.au/chapter-11-advertising.

15. Dewhirst T. New directions in tobacco promotion and brand communication. Tob Control 2009;18:161-2.

16. Hershberg P. What social media means for search. Advertising Age 2009;80:40.

17. Facebook. About Facebook. Facebook factsheet, 2009. http://www.facebook.com/ home.php\#/press/info.php?factsheet (accessed 21 Apr 2009).

18. Hempel J, Kowitt B. How facebook is taking over our lives. Fortune International 2009;159:48-56.

19. Facebook. Mobile. Statistics, 2009. http://www.facebook.com/press/info.php? statistics\#/press/info.php?statistics (accessed 14 Dec 2009).

20. GSM Association. GSM mobile phone technology adds another billion connections in just 30 months, 2006. http://www.gsmworld.com/newsroom/press-releases/ 2047.htm (accessed 29 Jun 2009)

21. Hodgson A. The global digital divide. Euromonitor International, 2007. http://www euromonitor.com/Articles.aspx?folder=The global digital dividegprint=true (accessed 28 Jun 2009)

22. Callard C, Collishaw N, Swenarchuk M. An introduction to international trade agreements and their impact on public health measures to reduce tobacco use. Physicians for a Smoke-Free Canada, 2001. http://smoke-free.ca/pdf 1/ TradeधTobacco-April\%202000.pdf (accessed 29 Jun 2009).

23. Lee K. Globalization and health: an introduction. Hampshire: Palgrave, 2003

24. Freeman B, Chapman S. Open source marketing: Camel cigarette brand marketing in the "Web 2.0" world. Tob Control 2009:18:212-17.

25. Anderson SJ, Ling PM. "And they told two friends. and so on": RJ Reynolds' viral marketing of Eclipse and its potential to mislead the public. Tob Control 2008;17:222-9.

26. National Cancer Institute. The Role of the Media in Promoting and Reducing Tobacco Use. Tobacco Control Monograph No. 19. Bethesda, MD: US Department of Health and Human Services; 2008 Jun, National Institutes of Health, National Cancer Institute. NIH Publication No. 07-6242. Chapter 15. Future directions. http://cancercontrol.cancer.gov/tcrb/monographs/19/m19 15.pdf laccessed 22 Apr 2009).

27. Collin J, Kelley L, Gilmore A. Unlocking the corporate documents of British American Tobacco: an invaluable global resource needs radically improved access. Lancet 2004;363:1746-7.

28. Raacke J, Bonds-Raacke J. MySpace and Facebook: applying the uses and gratifications theory to exploring friend-networking sites. Cyberpsychol Behav 2008;11:169-74

29. Ybarra ML, Mitchell KJ. How risky are social networking sites? A comparison of places online where youth sexual solicitation and harassment occurs. Pediatrics 2008; 121:e350-7. 
30. Muise A, Christofides E, Desmarais S. More information than you ever wanted: Does Facebook bring out the green-eyed monster of jealousy? Cyberpsychol Behav 2009. [Epub ahead of print].

31. Carter S. Worshipping at the Alpine altar: promoting tobacco in a world without advertising. Tob Control 2001;10:391-3.

32. Assunta M, Chapman S. "The world's most hostile environment": how the tobacco industry circumvented Singapore's advertising ban. Tob Control 2004;13(Suppl 2): iij $51-7$.

33. Freeman B, Chapman S. Is "YouTube" telling or selling you something? Tobacco content on the YouTube video-sharing website. Tob Control 2007;16:207-10.

34. The Economist. Primates on Facebook. Science and technology, 2009. http://www. economist.com/sciencetechnology/displayStory.cfm?story id=13176775 laccessed 10 Jul 2009).

35. Facebook. Facebook Pages, 2009. http://www.facebook.com/home.php? ref=home\#/advertising/?pages (accessed 30 Jun 2009)

36. O'Neill N. Facebook pages have become your friends, can be added to friend lists. All Facebook, 2009. http://www.allfacebook.com/2009/06/facebook-page-friends/ \#more-6356 (accessed 29 Jun 2009).

37. British American Tobacco. Our global drive brands. 2009. http://www.bat.com/ groupfs/sites/BAT 7AWFS6.nsf/vwPagesWebLive/D07B5NPH? opendocument\&SKN$=1$ (accessed 14 Jun 2009).

38. O'Neill N. The 5 Phases of the Facebook sales funnel. All Facebook, 2009. http:// www.allfacebook.com/2009/06/facebook-sales-funnel/\#more-6329 (accessed 30 Jun 2009).
39. Sullivan EA. Guerrillas in the mist. Marketing News 2009:43:06

40. BBC News. Bannatyne takes on big tobacco. This World, 2008. http://news.bbc.co. uk/1/hi/programmes/this_world/7477468.stm (accessed 28 Apr 2009).

41. Brand New Machine. Brand new Machine + Dunhill presents *** the EXHIBITIONIST ***. Facebook event. 2009

42. Ash UK. You've got to be kidding: How BAT promotes its brands to young people around the world, 2007. http://www.oxygeneve.ch/docs/bat-you\%27ve-got-to-bekidding.pdf (accessed 30 Jun 2009).

43. Lucky Strike and Co. Lucky Strike. Lucky Night !!! Facebook event. 2009. (accessed)

44. Facebook. What is an admin? How do I add group admins? 2009. http://www facebook.com/help.php?page =826 (accessed 1 Jul 2009)

45. Greenstein H. Facebook pages vs Facebook groups: What's the difference? Mashable. The social media guide, 2009. http://mashable.com/2009/05/27/ facebook-page-vs-group/ (accessed 1 Jul 2009).

46. ABC News. Roxon orders Facebook tobacco probe, 2009. http:// www.abc.net.au/news/stories/2009/10/07/2707492.htm (accessed 23 Nov 2009).

47. Mangold WG, Faulds DJ. Social media: the new hybrid element of the promotion mix. Bus Horiz 2009:52:357-65.

48. Chapman S, Freeman B. Markers of the denormalisation of smoking and the tobacco industry. Tob Control 2008;17:25-31.

49. Palazzo G, Richter U. CSR business as usual? The case of the tobacco industry. $J$ Bus Ethics 2005;61:387-401. 